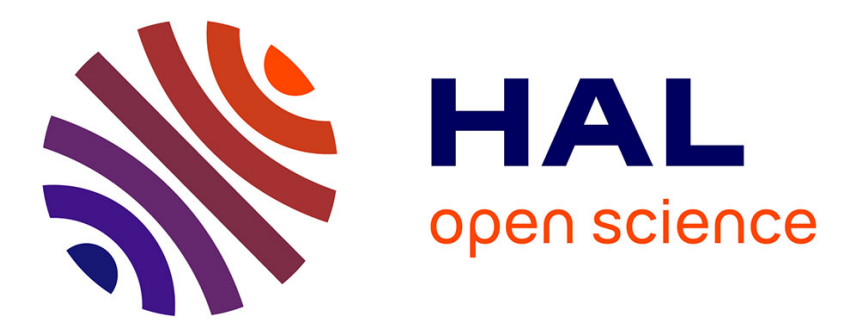

\title{
Erratum: Quasicontinuous Atom Laser in the Presence of Gravity [ Phys. Rev. Lett. 86, 4729 (2001)]
}

Fabrice Gerbier, Philippe Bouyer, Alain Aspect

\section{To cite this version:}

Fabrice Gerbier, Philippe Bouyer, Alain Aspect. Erratum: Quasicontinuous Atom Laser in the Presence of Gravity [ Phys. Rev. Lett. 86, 4729 (2001)]. Physical Review Letters, 2004, 93, pp.059905. 10.1103/PhysRevLett.93.059905 . hal-00008612

\section{HAL Id: hal-00008612 \\ https://hal.science/hal-00008612}

Submitted on 12 Apr 2016

HAL is a multi-disciplinary open access archive for the deposit and dissemination of scientific research documents, whether they are published or not. The documents may come from teaching and research institutions in France or abroad, or from public or private research centers.
L'archive ouverte pluridisciplinaire HAL, est destinée au dépôt et à la diffusion de documents scientifiques de niveau recherche, publiés ou non, émanant des établissements d'enseignement et de recherche français ou étrangers, des laboratoires publics ou privés. 


\title{
Erratum: Quasicontinuous Atom Laser in the Presence of Gravity [Phys. Rev. Lett. 86, 4729 (2001)]
}

\author{
F. Gerbier, P. Bouyer, and A. Aspect \\ (Received 28 May 2004; published 29 July 2004)
}

DOI: 10.1103/PhysRevLett.93.059905

PACS numbers: 03.75.-b, 03.75.Hh, 99.10.Cd

In a recent Letter [1], we analyzed theoretically the extraction of a quasicontinuous atom laser out of a trapped Bose-Einstein condensate. The explicit expression for the outcoupling rate given in this Letter was underestimated by a factor of 2, and the correct expression should read (using the notation of [1]):

$$
\frac{\Gamma}{\Omega_{\mathrm{rf}}^{2}} \approx \frac{15 \pi}{16} \frac{\hbar}{\Delta} \operatorname{Max}\left[0,1-\eta^{2}\right]^{2} .
$$

This mistake follows from an incorrect evaluation of the density of states $\rho_{z}$ in the gravitational potential, which should read $\rho_{z}\left(E_{z}\right)=(1 / \pi l) H^{1 / 2}$ instead of $\rho_{z}\left(E_{z}\right)=(1 / 2 \pi l) H^{1 / 2}$. Good agreement with the data of Bloch et al. [2] is then obtained by using a Rabi frequency $\Omega_{\mathrm{rf}}$ twice as small as the value given in [1]. (Note that this amounts to an overall rescaling of the curve, whose width and shape are not modified by the present correction.) This lies within the experimental uncertainty on the magnitude of the magnetic outcoupling field, whose determination is based on a calibration made at frequencies much lower than the radio frequencies used in the experiment [3]. A similar observation has already been made in [4]: The 3D numerical calculations reported in this paper showed a similar factor of 2 discrepancy between the calibrated $\Omega_{\mathrm{rf}}$ and the one that best reproduces the experiments. A new set of carefully calibrated data could certainly resolve this issue.

[1] F. Gerbier, P. Bouyer, and A. Aspect, Phys. Rev. Lett. 86, 4729 (2001).

[2] I. Bloch, T.W. Hänsch, and T. Esslinger, Phys. Rev. Lett. 82, 3008 (1999).

[3] T. Esslinger (private communication). Note that eddy currents or similar influence by nearby conductors tend to reduce the proportionality factor between the true magnetic field and the current in the coil, compared to the one deduced from a dc calibration. This is consistent with the sign of the deviation we find.

[4] Y. Japha and B. Segev, Phys. Rev. A 65, 063411 (2000). 